
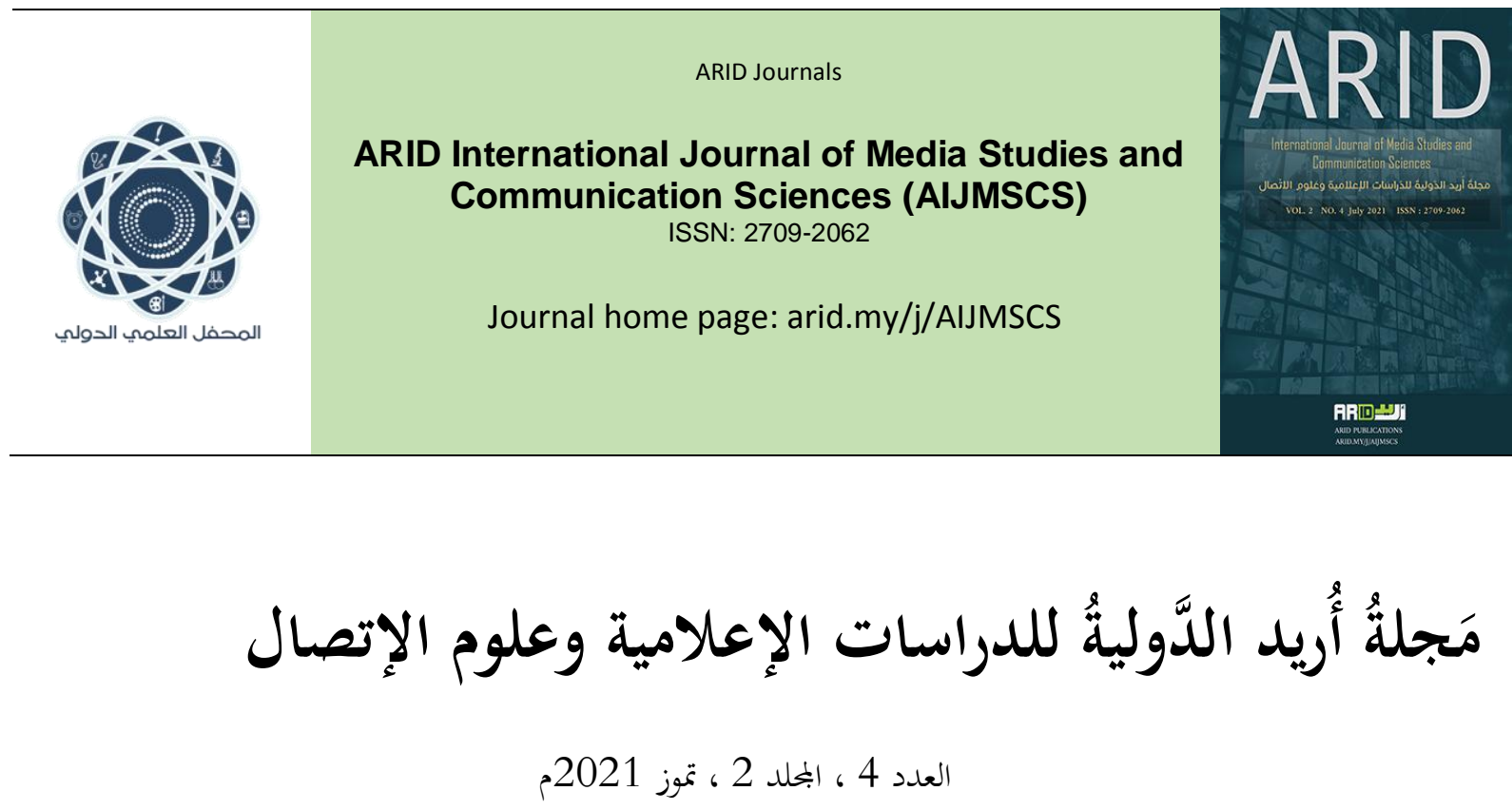

\title{
The Role of Media Education in Building the Concept of Sustainable Development
}

Mervat Rashad Ibrahim Muhammad Farrag

Ph.D. Researcher in Media, Certified International Trainer in Sustainability Applications, (Qatar Chamber), Qatar

دور التربية الإعلامية وبناء مفهوم التتمية المستدامة

ميرفت رشاد ابر اهيم محمد 


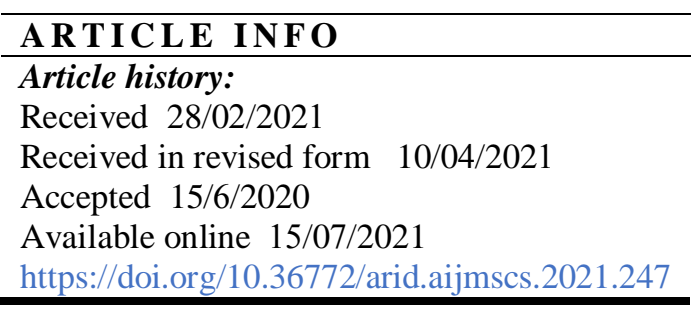

\begin{abstract}
The reality of media education in secondary schools from the perspective of teachers in Qatar. The research significance focused on study the importance of the role of media education in building the concept and responsibilities of sustainable development among school students. The descriptive analytical approach was used to analyze and develop concepts and foundations in order to stand on the ground on the reality of media education and its impact on students in sustainable development. The study sample consisted of (100) teachers and teachers from secondary schools, which were divided by (50) teachers from secondary schools for boys and (50) female school teachers, who were selected in a simple random way. Using the questionnaire form to collect information for the specific sample. The results of the study showed that: $85 \%$ of the research sample agreed that media education helps students to form their personality. $39 \%$ of the sample agreed that media education is effective and has prominent activities in secondary schools. And $58 \%$ of the research sample agree that there is an activation of the means of technology in media education in secondary schools. And $32 \%$ of the sample believe that there are many media education activities in secondary schools
\end{abstract}




\section{الملخص}

تكمُن أهمية البحث فى مدى أهميـة دور التربيـة الإعلاميـة في بنـاء مفهوم ومسؤوليات التنميـة المستدامة لدى طلاب المدارس

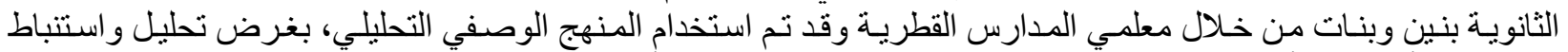

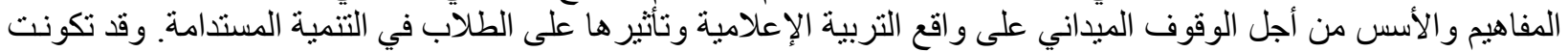

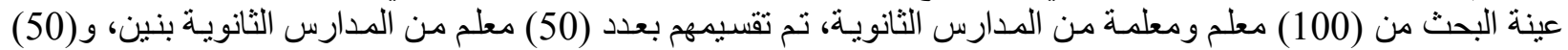

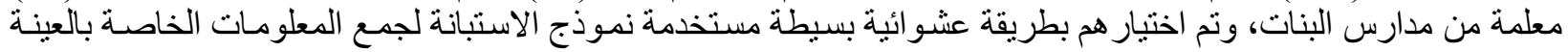
المحددة.

$$
\text { وأظهرت نتائج البحث أن: }
$$

1- نسبة 85 \% من عينة البحث تو افق على أن التربية الاعلامية تساعد الطلاب على تكوين شخصيتهم. 2- ونسبة 39 \% من عينة البحث تتفق على أن التربية الإعلامية فعالة ولها أنشطة بارزة في المدارس الثانوي. 3- ونسبة 58 \% من عينة البحث ثتفق على أنه يوجد تفعيل لوسائل التكنولوجيا في التربية الإعلامية بالمدارس الثانوية. 4- ونسبة 32 \% من عينة البحث ترى أن هنالك العديد من أنشطة التربية الإعلامية بالمدارس الثانوية. 5- ونسبة 39 \% من عينة البحث ثتفق على أن هناك تشجيع للطلاب على المشاركة في أنشطة التربية الإعلامبة. 6 ونسبة 59 \% من عينة البحث تو افق على أن التربية الإعلامية تسهم في بناء منظومة القيم لدى طلاب المرحلة الثانوية. 7 - ونسبة 55 \% من عينـة البحث تو افق على أن التربيـة الإعلامبـة تسـهم في بـث روح الولاء و الإنتمـاء للوطن لدى طلاب المرحلة الثانوية. 


\section{Research Summary}

The reality of media education in secondary schools from the perspective of teachers in Qatar.

The research significance focused on study the importance of the role of media education in building the concept and responsibilities of sustainable development among school students. The descriptive analytical approach was used to analyze and develop concepts and foundations in order to stand on the ground on the reality of media education and its impact on students in sustainable development. The study sample consisted of (100) teachers and teachers from secondary schools, which were divided by (50) teachers from secondary schools for boys and (50) female school teachers, who were selected in a simple random way. Using the questionnaire form to collect information for the specific sample.

The results of the study showed that: $85 \%$ of the research sample agreed that media education helps students to form their personality. $39 \%$ of the sample agreed that media education is effective and has prominent activities in secondary schools. And 58\% of the research sample agree that there is an activation of the means of technology in media education in secondary schools. And $32 \%$ of the sample believe that there are many media education activities in secondary schools. And 39\% of the sample agree that students are encouraged to participate in media education activities. $59 \%$ of the sample agree that higher education contributes to building the value system among high school students. And 55\% of the sample agree that media education contributes to spreading the spirit of loyalty and belonging to the homeland among high school students. 


\section{Introduction:}

The media is an essential mechanism for bringing about change within Community as well as to connect the various interactions that It can be created among its members because the media is an important concept Different dimensions and being a stand-alone science has its origins And its unique terminology, like other fields Cognitive as he examines the study, analysis, description, and such Addressing various social and political phenomena Economic and environmental to other phenomena that It is governed by the enormous development mechanism in various fields.

The media in the modern era also plays an important role. Moreover, influencing the lives of individuals and societies. Furthermore, the media is the objective expression of a mindset. The masses and their spirit and tendencies and trends in the same

Time, as Outgrot put it, is imperative. There are three fundamental characteristics in the media, namely. Novelty, modernity, importance and magnitude, accuracy And objectivity (Ajwa, 2014), The media has been tightened his world domination, entertaining, nurturing and directing, appears every day with a new face, and every period and stage with a style innovative, with fantastic technology, beyond the limits and the place. which made education through its multiple means, its cautious, gradual development will lose its grip on satisfied it, and the media has the largest share in socializing, influencing and mentoring, and nurturing young and old, the media occupies a privileged position in our contemporary reality, based on the nature of its functions and their roles, through their impact on the individual and society, and the media in contemporary society plays a significant role in the upbringing of individuals, especially as its impact reaches sectors a broad spectrum of society. which is compounded the influence of the media overlapping its functions with the functions community institutions, especially institutions educational institutions, accordingly, are prepared from the most important institutions that 
should realize the importance of the media is working to take advantage of its functions in its educational programs aimed at developing knowledge Students, and positively building their attitudes and convictions to contribute to the development of society. from this point of view, it became necessary to take care of educational institutions with societal aspects surrounding the student, and that includes the curriculum all kinds of activities that surround the student at home and school, community, and attention at the same time by measuring the influence of the media on his personality and his ability to understand the media message being exposed her consciously and critically, and this is what is translated through the concept of "media education." media education is described in the context of the world talking is like a human building process, helping to use of quality media, designed to shape the culture of interaction with those means, and the development of skills innovative and communicative, critical thinking, and reception, interpretation, analysis, and evaluation of informational texts, and teach all self-expression pictures using media technology (Baranov, 2012).

\section{Importance of research:}

The research significance focused on study the importance of the role of education Informative in building the concept and responsibilities of sustainable development among students Schools, and we can determine the importance in the following:

\section{Scientific importance:}

Lies in defining the roles and tasks of education Information in building generations and modifying their concepts towards a system's Values and belonging to the homeland.

\section{Social significance:}

Building students able to understand variables from their social relations in the light of media education. 


\section{Educational importance:}

The lack of such an educational library and Arabic Types of educational research.

\section{Research objectives:}

1 - Knowing the reality of media education from the teachers' perspective in secondary schools in the State of Qatar.

2- Defining the teachers' view of media education in secondary schools.

3 - Defining media education's role in spreading the spirit of loyalty and loyalty to the homeland among high school students.

4 - The role of media education in building the student's personality and values the perspective of teachers in secondary schools in the State of Qatar.

\section{Research problem:}

- The debate about the relationship between education and the media is not new. Studies and researches that have been covered have clarified the relationship that there are many aspects of the approach and paradox between them. The technological development imposed an important aspect integration between media and education and that the media has become a focus one of the axes of the educational process, and educational media has been included within the educational specializations spread in educational institutions (Hamdan, 2004). The technological revolution has made education media is more urgent, especially after the countries lost control full-on live T.V programming, and lost its ability to confront foreign media broadcasts and sweep foreign cultural. After the internet helped invade cultural threat and many national cultures, and interact with the young people. Youth and adults in dealing with cultural and 
sectarian currents and political chaos (Hamdan, 2004) the external media sphere, and with competition and conflict between styles national culture and foreign cultures.

The influence appeared evident for newspapers, magazines, children's books, adventure films, and programs television and internet sites on deviant behavior and violent crime aggression, especially in children and adolescents, the influence on many concepts, values, customs, and cultural identity. Moreover, the educational institution became more qualified than other institutions to enable students to have a rational and aware media culture; in this way, the problem crystallizes in the following central question:

- What is the reality of media education in secondary schools from a perspective of Teachers in Qatar?

Several sub-questions are divided from this central question, namely:

1 - What is the school's role in encouraging students to conduct media education activities from the teachers' perspective in Qatar's secondary schools?

2 - What is the function of media education in spreading the spirit of belonging and loyalty to the homeland among students from teachers' perspectives in secondary schools in the State of Qatar?

3 - What are media education's role in building the student's personality and values from the teachers' perspective in secondary schools in Qatar?

\section{Theoretical and conceptual framework:}

\section{First Concepts and Terminology:}

Media in Language:

It is the notification or reporting, i.e., the receipt. 
Idiomatically:

Providing accurate news and information For people, and the facts that help them realize what is going on around them And forming correct opinions in all matters that concern them (AlDulaimi, 2011).

\section{Educational media:}

Uses media to serve everything related to Educational (Omar et al., 2011).

Most societies today witness open or hidden Competition, Announced or hidden, between the educational and media systems, and this resulted Competition breeds dangerous contradictions in one's mind and ways of thinking.

The educational system is based on the values of the system represented in the content disciplined study. On the values of Competition in achievement and achievement of self-learning and individualization of education. In contrast, the system is based Media to the mass communication who is interested in the new without contemplation In its content, and in various topics without focusing on specialization Specifically, and presenting entertaining entertainment programs that are easy to understand regardless of the thinness of the methods or the insignificance of the vocabulary, this appears the contradiction between the educational and media systems.

This contradiction resulted in a collision of the existing relationship between educational and media institutions. In addition, the emergence of clear contrast between School cultures based on knowledge of an academic nature Pedagogical, and between the media culture promoted by the media Recreational in nature based on excitement and publicity. Despite the cultural difference provided by educational and media institutions, Despite the contradiction in their goals, objectives, means, and methods, it is not that there are areas of homogeneity and similarity 
between the two educational institutions and informational. Both are a process of communication, and both contribute to nurturing a social person who spends a long period of his life watching media or educated within the classroom. Instead, the current generation's share of the influence of the mass media In forming his culture, defining his behavior patterns, and imparting concepts and values Habits and trends, has significantly increased with the advancement of communication technology And information, and space congestion with satellites that broadcast their programs All night and day. This requires overcoming the existing rupture between Educators, media professionals, and cooperation in employing the media in serving specific educational purposes, and employing education in activating messages Informational. The recent technical developments, the institution's position has shifted the pedagogical means of communication technology, and media institutions have become means Media and information technology are used in the core of the educational process. The teacher use of multimedia and international information network in preparing educational experiences and communicating them to students, education has become Distance, e-learning, virtual university, and websites Educational fields are essential on which the educational institution relies (essence, 2004).

\section{The role of media and educational institutions:}

The media plays a significant role in the modern society in the upbringing of individuals, especially as its influence reaches broad sectors and broad segments of society, and this has been helped by the speed of its shortening of time and place, and its rapid response to scientific and technological developments, which leads to an increase in the cultural balance For human beings and facilitate the exchange of human experiences. The media have several advantages that other educational media do not have. They provide diverse cultural experiences, behavioral models, and ways of life for broad sectors of society. They also transfer to individuals experiences that 
are not in the field of their direct environmental and social interactions, and the media are exposed to many political, economic, and social issues, which makes them have a significant influence on forming and directing public opinion and an essential means of continuous education (Al-Khatib, 2004 AD, 178).

The media has a prominent and influential role in the process of social upbringing because of its characteristics that enhance its role, including its attractiveness that raises the interests of young people and fills a large part of their free time, mainly as it reflects the general culture of society, and the subcultures of different social groups, and informs people about topics, ideas and facts And news, information and knowledge in all aspects of life », in addition to that it attracts the audience to desirable behavioral patterns, and achieves pleasure for them through various means around the clock to satisfy their needs. With an organized educational process that keeps pace with this fantastic development, it will lead to confusion, randomness, and even loss in the educational process, if developed countries can control the international media. It is the creation of international news agencies, in addition to international radio, newspapers, and magazines spread on a global scale, the power of the World Wide Web (the Internet) and the use of satellites, shortening distances and shortening time, making the media a dangerous weapon in the hands of major powers, and posing a challenge to developing countries and countries. Poor women to escape the restrictions of media dependency (Khadour, 2003).

The media owns several public means, the most important of which are: television, radio, the Internet, paper and electronic press, exhibitions, museums, theater, cinema, libraries, and others, and the development in these media has been amazing, making the world approach and overlap through a network of communications and optical spectrums, and overcoming barriers of time and space, The media has become one of the determinants of behavior, or one of the factors that strongly influence it. 
The satellite channels, Other media have become an irresistible influence on children's behavior (Al-Owaini, 1983). Faced with this media role that influences thinking, values, behavior, and emotions, it has become necessary for educators and media professionals to join hands to promote the educational media process and develop its role in contemporary society.

\section{The function of education in contemporary society:}

Education, in its essence, is a human process linked to the existence of man on earth and continues with the continuity of life. The relationship between man and society and education is close. Since human societies differ in their culture, philosophies, and outlook on human nature and objectives, they also differed in the concept of education, its philosophy, its goals, and the role it plays in society. Education is one of the broadest fields that are not surrounded by research; it is not it is limited to a specific stage of the individual's life, but rather a continuous process as long as his life continues, and it is a process that means all the educational and cultural influences that the individual is exposed to in away. Systems are directed through specialized or non-specialized educational institutions, formally or informally, intended, or unintended, affecting socialization.

Thus, in its general meaning, education becomes the development of the human personality in a direction that achieves the good of man, the good of his society, and the good of humanity (Hassan et al., 1987). During the upbringing, the human characteristic of his behavior shaped his behavior by some educational institutions and media such as the school, the family, the mosque, the peer group, the clubs, and the media. The trends and values that achieve him successfully interact with different life situations and deepen his understanding of his social roles.

For this, coordination and cooperation between these educational media is the supreme goal that society seeks to integrate the education of young people. That cooperation becomes a start to 
achieve the Arab and Islamic society's comprehensive development and achieve coexistence Positive with the international community (Metwally, 2004).

\section{The approach and paradox between the role of the media and the role of education in contemporary society:}

Education is an interdisciplinary science with close ties to other sciences, both human and natural. It is possible to distinguish between the role of the media and the role of education in contemporary society as follows:

1- The media is distinguished by its rapid response to scientific and technological developments, and this matter is not available for education. Just as there are several other advantages that other educational media do not have in the media, as they provide various cultural experiences, behavioral models, and ways of life of large sectors of society, Besides, it conveys to individuals experiences that are not in the field of their direct environmental and social interactions.

2- The media reflects the society's general culture, along with the subcultures of the different social groups, through the subjects, information, ideas, news, and attitudes of various aspects of life that its various means transmit to its broad audience. In contrast, the school culture is limited to the academic courses that derive their origins from the community's cultural heritage. The basic structure of the field of knowledge that students learn.

3- The media provides its audience with vast opportunities for entertainment, recreation, and fun, and this is what education does not provide to its students. Education often suffers from rigid curricula that do not meet students' interests or satisfy their interests and needs, and teaching methods are often based on recitation, and exams are often terrifying and fearful. From its results. 
4- The speed of the spread of the media and its effect in shaping the minds of the masses through direct and indirect means of persuasion, and through effective dialogue. the quality of the technique of sound and kinetic effects, the flexibility and diversity of the programs to satisfy all tastes, different cultural levels, and different age groups, and the transfer of live direct experiences from anywhere in Maamoura, This is not easy to implement on the educational media or assume responsibility for.

5- Education affects the development of the human being, a balanced development integrated into the body, mentally, morally, emotionally, ideologically, socially, and culturally so that his personality grows to the maximum extent his capabilities allow. Education also helps students and students with concepts, trends, values, information, and skills that help them coexist with others and form social and stable relationships. With them is based on understanding, respect, and trust, and this is what the media can do as unintended educational means that they cannot follow or modify behavior.

The media provides a news service that aims to enlightenment, enlightenment, and persuasion to achieve adaptation and mutual understanding. Education is concerned with transmitting cultural and civilizational heritage after its purification to successive generations and developing their skills and mental abilities. The motivation in education and learning is clear, while the clarity disappears in the media's motivation.

Education is distinguished from media in the direct reciprocal link between the learner and the teacher, while this relationship disappears in media institutions. 


\section{Media education:}

Media education is the process of employing communication optimally to achieve the educational goals set out in the educational policy and the media policy of the state. Therefore, its influence is not limited to students in the school, but rather it affects fathers, mothers, brothers, and sisters within the family, and affects all members of society (Shehata 2003)

The educational media is required to follow the behavior of students inside the school and in the community, and to assure them of the necessity to preserve the school in its building and meaning, and to preserve the behavior of the student of knowledge by displaying decent morals, respect for the teacher, love for parents, an urgent desire for knowledge, love for his colleagues, loyalty to his country, and preservation Order, cleanliness, distance from everything that is disgraceful, cooperation in goodness, connection with family and society, preservation of the environment, and the characteristics of the honorable and genuine Arab Muslim. The educational media is required to be a helper for parents in bringing information closer to the minds of students, encouraging them to acquire knowledge and knowledge, inculcate noble Islamic values, live with the conditions of society, and confirm the actual concepts of education, work, and belonging to the homeland.

\section{Objectives of educational media:}

Educational media seeks to achieve the following goals (El-Sawy and Sharaf, 1998):

1- Participating in inculcating and disseminating the Islamic faith, providing the recipients with Islamic values and teachings and ideals, developing constructive behavioral trends, and advancing the recipients' educational, intellectual, cultural, and emotional levels.

2- Preserving and disseminating the Islamic educational heritage and introducing it to its people and their educational and scientific efforts. 
3- Developing intellectual trends that enhance social cohesion and achieve the formation of conscience that guides the individual's behavior in life and strengthens social control among student groups.

4- Participation in spreading educational awareness at the level of the various educational sectors, at the level of society in general, and the family in particular.

5- Emphasizing that the new generation is the real wealth of society and that caring for, caring for, and educating them is a general responsibility in which everyone must participate.

6- Coordination between educational institutions and media institutions to pursue integration in goals, programs, and activities.

7 - Objective coverage of the various aspects of the educational process and the documentation of its activities.

8- Adopting education, educators, and students' issues and problems and addressing them in the media.

9- Highlighting the school's role as the primary means of education in society and emphasizing the need to support and fulfill its mission.

10- Creating media channels for continuing education, distance education, and education for special needs people.

11- Strengthening the link between officials, workers, and those interested in education affairs in the Kingdom, and developing awareness of the teacher's message and his place in society.

12- Introducing recent developments in educational thought, educational and informational technologies, and encouraging research in the field of educational media. 


\section{Foundations of educational media:}

Educational media is based on several foundations and starting points, the most important of which is the following (El-Sawy and Sharaf 1998)

1- Commitment to Islam and its complete perceptions of the universe, man and life, preserving the ummah's belief, and believing that the Muhammadiyah message is the best approach to a virtuous life that achieves happiness for human beings, and the media avoids everything that contradicts the Islamic law.

2- The close connection with the Islamic nation's heritage, history, and civilization and benefit from our great ancestors' biographies and our historical monuments.

3- Deepening the sentiment of loyalty to the homeland by introducing its message, its characteristics and gains, and educating the citizen about his role in the nation's renaissance and progress, and preserving its wealth and achievements.

4- Focusing on the pillars of the educational process in the media message (school - curriculum teacher-student and guardian) and contributing to the definition of their roles in the educational process, duties and rights, problems, and address them in the media.

5- Emphasizing that classical Arabic is the receptacle of Islam and its culture's repository, it should be adhered to as a language for media education.

6- Adherence to objectivity in presenting facts, avoiding exaggerations, and appreciating the word's honor and the necessity to protect it from absurdity.

7- Conscious interaction with global civilizational developments in science, culture, and literature, participating in them and directing them in a way that benefits society in particular, and humanity in general with good and progress. 


\section{Educational media:}

The media includes several mass media, the most important: the Internet, television, radio and the press, exhibitions, museums, seminars, theater, libraries, social activities, lectures, and seminars. Below, the participant discusses the role of some of them in media education.

\section{School media education:}

School media education achieves several educational goals, represented in several discussion matters, including increasing school educational work effectiveness, confronting civilizational challenges, and improving school student life.

Here is a summary of those goals. School media education plays a significant role in developing and increasing the effectiveness of school educational work through the following practices (United Arab Emirates University, 1996):

(A) Contribute to providing the link between school and life.

(B) Contribution to social cohesion.

(C) Helping students to understand different worldviews and visions.

(D) Promote students' concepts of shura.

(E) To address students' complex problems such as poverty, drugs, homelessness, hunger, gangs, and unemployment.

(F) Helping schools achieve a correct understanding among students of the concepts of social justice and social solidarity.

(G) To accustom students to take responsibility and to consolidate the roots of cooperation

. (H) Helping students to understand the implications of vocational education. 
Facing civilization challenges:

The emergence and spread of globalization have been accompanied by many global challenges in the cultural, social, political, and economic fields. The most prominent of which are cultural penetration and the spread of the culture of globalization, and this requires school media education to help students face many of these civilizational and cultural challenges, the most prominent of which are (Mitwalli, El Helwa, Delor, et al. 1996).
A. Promote Islamic religious identity.
B. Facing value change
C. Meeting the challenge of cultural communication
D. Confronting tensions between local and global
E. Confronting the tension between tradition and modernity
F. Confronting the tension between the spiritual and the material.
G. Confronting the tension between the macro and the private
H. Confronting the tension between the long term and the short term

School media education deals with a large number of fields and areas related to the students' school life and life, the most important of which is

A. Helping the school create a real learning environment, in which understanding, frankness, and dialogue are the most prominent mechanisms and methodologies.

B. Enhancing the virtual school's prestige in being an institution for imparting students to values.

C. Helping students in their schools reconfigure negative perceptions about things and people to be optimistic after the confusion becomes more transparent and the ambiguity 
is removed, and media education can make what is unsafe at the school level for one or more students.

D. Media education helps schools and students to transcend narrow boundaries and to go beyond them to broader, more comprehensive and comprehensive limits.

E. Media education enables schools to self-assess and re-develop oneself in a new form and content suited to contemporary circumstances and requirements

F. Helping students to have continuous success that does not stop at a specific limit.

G. Media education enables students to embark on bold adventures in educational work, so traditional obstacles (teacher, writers, the prevailing school system, means, and school administration) do not become a reason for their lack of access to information and creativity achievement.

H. Media education helps form student leaders and makes the school itself a leadership school for other schools under its activities, achievements, and initiatives.

I. School media education provides a scientific and cultural cover suitable for many schools and its students' plans and programs.

J. School media education enables its students to develop and reform the local environment and create a rapprochement between its residents and cohesion among its members. Hence, the school benefits from this transformation in pushing the wheel of school development to the maximum possible speed.

K. School media education helps its students to share with their peers in similar schools' perceptions and visions about schoolwork, both at the district and national levels. 


\section{Fields of school media education:}

There are many fields from which school media education starts, the most important of which are the following (Al-Ali, 2002)

\section{School games:}

Synthetic, representational, or kinetic school games can be a good source of educational information in public education schools with correct concepts about games, their methods of performance, the objectives behind them, an understanding of the values and ideals associated with them, and the promotion of the principle of fair competition, a good appreciation of the performance of others or others, and the importance Preparation and premobilization, discipline, perseverance, patience, and endurance.

In addition to this, school games develop students' linguistic structures and accurate expressions and enable them to be creative in necessary skills, skills of quick and intuitive attention and attention distribution, social and communicative skills, enhancing concepts of public health, physical health, and physical care, avoiding injuries and diseases, and enabling the student to social maturity and balance Emotional education and getting rid of the problems of selfishness, authoritarianism, narrow-mindedness, and isolation from the group, and school media education achieves many educational and cultural goals through playing, such as knowing the nature of games, their inventors, factories, quality level, risks, damages, advantages and disadvantages (Al-Ali, 2002). 


\section{School arts:}

School arts cover a large area of student activities such as drawing, decoration, sculpture, handicrafts, performing and theatrical arts, chants, songs and educational songs, student museums, student production exhibitions, school parties, festivals, and others.

All of these arts can achieve the goals of school media education intensively and quickly, and the impact of learning these arts in school remains in the same student for long periods and is a cause for many feats in his whole life.

There are many types of paintings, artistic works, performances, plays, exhibitions, historical, military, architectural, scientific, natural and artistic museums, hobby fairs, religious and national event exhibitions, book fairs, and educational exhibitions that students can benefit from (Habib, 2003).

\section{School Radio and Press:}

Both the radio and the school press constitute a central focus in which thousands of media messages are gathered that achieve fundamental educational goals. The school radio and press's success depends on the excellent choice of the media material, the method of its presentation, and its suitability for the situation. Also, the modernity of the media material and its presenter or preparer's skills play a vital role in making it acceptable to others. School radio and school press enable them to keep pace with the event and give students opportunities to participate in talking about it, presenting their opinions about it, criticizing it, evaluating it, and linking it to various aspects of life. School radio and school journalism enable students in schools to acquire leadership skills, public speaking and delivery skills, journalistic editing skills, investigative preparation skills, methods and sources of 
information data, and the characteristics of producing them in a format that achieves their intended goals (Charles and Glaser, 1997).

\section{Advantages of school media education:}

School media education brings many advantages for students, the most prominent of which can be identified as follows (Hareb, 2003):

1. To accustom students to coexist with the social, cultural, economic, political, and technological change dictated by rapid developments in ideas, values, visions, techniques, tools, and means.

2. Preparing students for coexistence with others, understanding with others, and recognizing and understanding local, regional, and international issues.

3. Help students explain and understand things, participate in problem-solving, and possess analytical skills and abilities.

4. Providing students with several gains within the framework of public mobilization to confront an emergency or ongoing event, and the ability to confront instead of fear, surrender isolation, or rejection for mere rejection or sufficiency by merely justifying issues and matters or dropping charges on others or attributing the issue or case for one specific reason. Without others.

5. Helping students realize their positions with others, whether these others are at home or abroad, so school media education will thus be an essential means for correcting concepts that contain the factors of division, difference, blameworthy differentiation, impressionistic images, and counter images. 
6. Helping students to understand their rights and duties, the rights of others and their duties, in addition to understanding many common concepts such as the concept of shura versus democracy, the concept of human rights, the concept of women's rights, the concept of freedom, the concept of minorities, the concept of privacy, and others.

7. Helping students to understand the meanings of globalization, what it is, ways to interact with it, its dangers, methods of purifying and properly employing it for the service of the individual and the group, the relationship of globalization with culture, the nature of major cultural projects such as the Middle Eastern concept, the concept of international transcontinental companies, the concept of political pluralism, the concept of the GATT, and the concept of Privatization, the concept of interfaith dialogue, civilization dialogue, the concept of Westernization, the concept of value change, and the concept of technology localization.

8. Helping students get rid of many psychological, cultural, and social problems and reunderstand things correctly with a modern tendency. Instead, school media education can help solve significant problems such as cultural illiteracy, technological illiteracy, political illiteracy, and the like.

9. Accustom students to love the school library and the book, and the desire to read, as it is a means of awareness, education, and treatment.

Helping students understand the societal and global culture and relate study materials to real events and facts.

10. Preparing media programs for children and youth of general education age that express their needs, satisfy their demands, upgrade their tastes, correct their ideas, and organize their lives. 
11. Helping male and female teachers, parents, and those who fall under their judgment to acquire the educational culture that guides their work and makes them able to know the attitudes of their sons and daughters and students in everything that would care for and educate young people.

12. Promoting the correct cultural selection of entertainment and cultural media programs while providing students with critical analysis and problem-solving skills.

13. Developing students' reading, writing, analytical, cognitive, and critical skills, and assisting in their proper social upbringing.

14. Immunization of students from cultural and civilizational influences harmful to values, beliefs, and local culture.

15. Training male and female students on the mechanisms of searching for information and ways to classify, organize, and analyze it, come up with results, and make judgments about these results.

16. Training students in scientific thinking by enhancing the concepts of listening and objectivity, distributing roles, suspense, methods of competition and dialogue, asking exciting questions, giving students sufficient opportunity to express themselves and private opinions, and on ways to formulate precise phrases and expressions that directly indicate the topic.

17. Students participate in planning various media activities and programs, either individually or collectively.

18. Providing various learning resources, paper, and electronic, helps students understand, comprehend, mastery, and creativity. 


\section{Barriers to School Media Education:}

Despite the recognition of all those in charge of the education of the importance of school media education, reality brings us to some problems that prevent the effectiveness of this education, and among the most prominent of these obstacles are the following:

1. Real lack of belief in the value and importance of school activities and parents' negative perception towards them.

2. The inability of teachers to systematically organize school activities that leads to achieving its goals.

3. The lack of time required in the school curriculum to practice the activity.

4. The examination system, and attention to them, which contributes to a large share in reducing school activity, and putting them in practice on the margin of importance, sometimes outside the margin limits.

5. The lack of a qualified teacher who can employ and invest in media technology for educational purposes.

6. The extreme contrast between the school culture and the culture promoted by the media.

7. In light of the progress of the means of communication and the crowding of space with satellites that transmit television programs to schools of the hour. it has become difficult to coordinate efforts between educators and media professionals to broadcast carefully planned programs to develop the capabilities of the Arab Muslim child within the framework of the constants of the Arab Islamic identity. 


\section{Previous studies:}

The study of William Nasson and Borden (1991) aimed at comparing two groups of students, one of whom received vocational guidance and the second did not receive any vocational guidance, and when comparing the two groups after the end of the school stage. It was found that the first group obtained good grades on the compatibility scale, and their grades grew Achievement is better than the achievement scores of the second group, and many other studies have been conducted on this topic.

all of which have reached an emphasis on the importance of the role that school, educational or professional media plays in helping students or trainees to make the appropriate decision regarding academic or The professional, through which he expresses the realization of the professional project in the future in Presenter, 1991

The study of Abdul Manan (1996). The subject matter was the realistic practices of guidance and counseling that high school students in some schools in the Kingdom of Saudi Arabia perceive. Educational and pedagogical.

\section{Employment of theory in research:}

Freedom theory (liberal theory)

This theory goes back mainly to the European Renaissance, specifically the eighteenth and nineteenth centuries, as several European thinkers crystallized many principles that challenged the authoritarian ideas that prevailed until the beginning of the European Renaissance. The most prominent of them was the English thinker John Merton, who wrote in 1664: "The freedom to publish in any medium and by any person, regardless of their ideological orientation, is a natural right of all human beings, and we cannot reduce the freedom to publish in any way and under 
any excuse. As for John Locke, he defined freedom as "the right to do whatever it allows Tags laws».

Locke had submitted to the English Parliament in 1665 a statement attacking the restriction of freedom of the press, and the parliament was forced at that time to repeal its law imposing preventive censorship on newspapers.

The first victory of liberal theory over authoritarian theory was achieved only during the eighteenth century when the British Parliament issued a decision affirming any prior censorship of publication. It also allowed individuals to publish newspapers without obtaining a license from the authority.

This cooperation came as a result of the English thinker Blackstone's ideas, who emphasized that freedom of the press is necessary for the existence of a free state, and that requires the absence of prior censorship on publication.

However, a journalist can be punished after publication if this publication includes a crime, and every person is free to publish whatever he wants. The public, and blocking this is destructive of the freedom of the press.

\section{Systematic procedures:}

The descriptive and analytical approach was used to analyze and derive the concepts and foundations that make up the theoretical framework for this topic, meaning that this approach provides detailed data on the actual reality of the phenomenon or the topic of research in order to examine the reality of media education and its impact on students in sustainable development. 


\section{Research community:}

Secondary schools in Qatar

\section{The sample:}

The study sample consisted of (100) teachers from secondary schools, who were divided into (50) teachers from secondary schools for boys, and (50) teachers from girls 'schools, and they were chosen in a simple random way.

\section{Data collection methods:}

The questionnaire form was used to collect information on the specific sample.

The limits of the study:

Temporal boundaries: 2018/2019

Spatial boundaries: secondary school teachers in the State of Qatar.

Thematic Limits: Media Education.

Data analysis: The questionnaire form was applied to a sample of male and female teachers in secondary schools in the State of Qatar.

\section{MEDIA EDUCATION HELPS STUDENTS MAKE UP THEIR PERSONALITY}

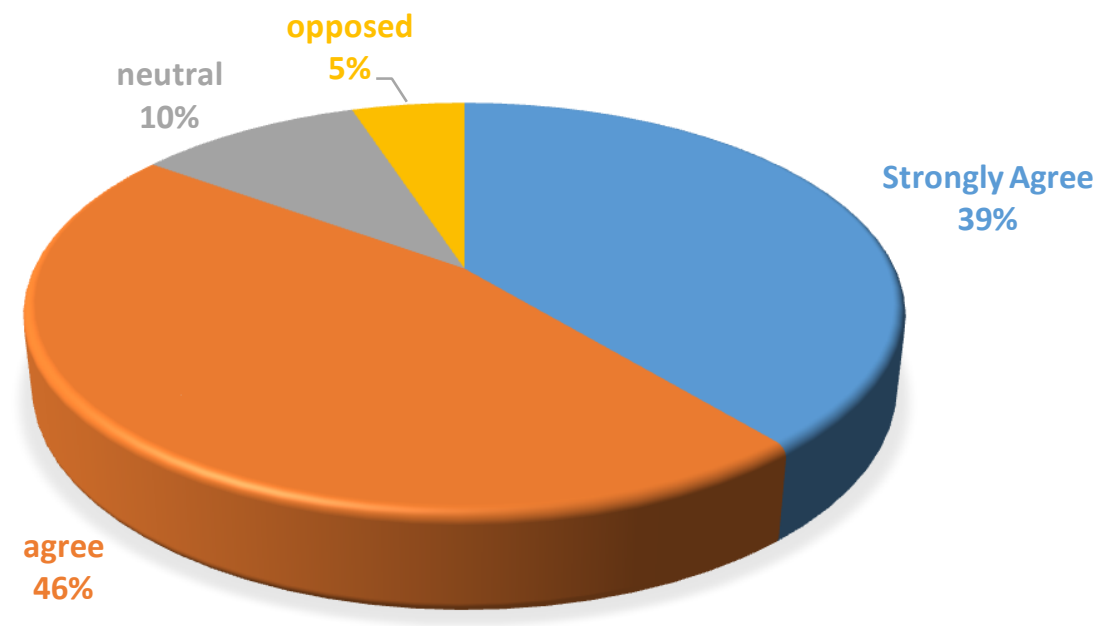


The questionnaire analysis on the research sample of high school teachers showed that media education helps students form their personality by $39 \%$ with a strongly agreed response, $46 \%$ with an agreement response, $10 \%$ neutral, and 5\% opposing.

\section{MEDIA EDUCATION WITHIN THE SCHOOL IS EFFECTIVE AND FOR HER NOTABLE ACTIVITIES}

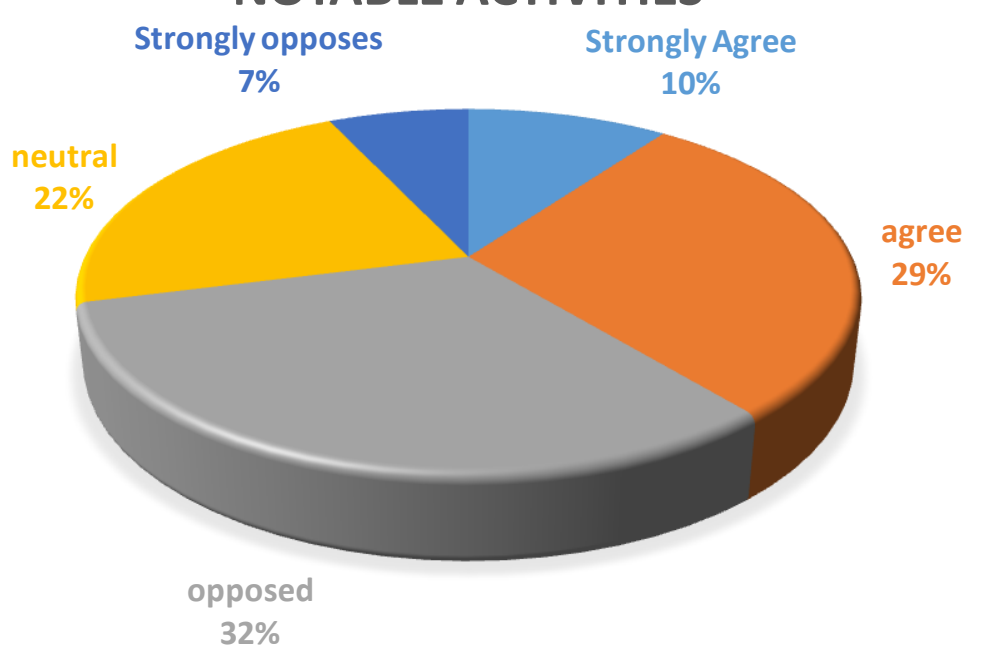

The questionnaire analysis on the research sample of high school teachers showed that media education within the school is significant and has prominent activities, with $10 \%$ strongly agree, $29 \%$ agree, $32 \%$ are against, $22 \%$ are neutral, and $7 \%$ strongly oppose. 


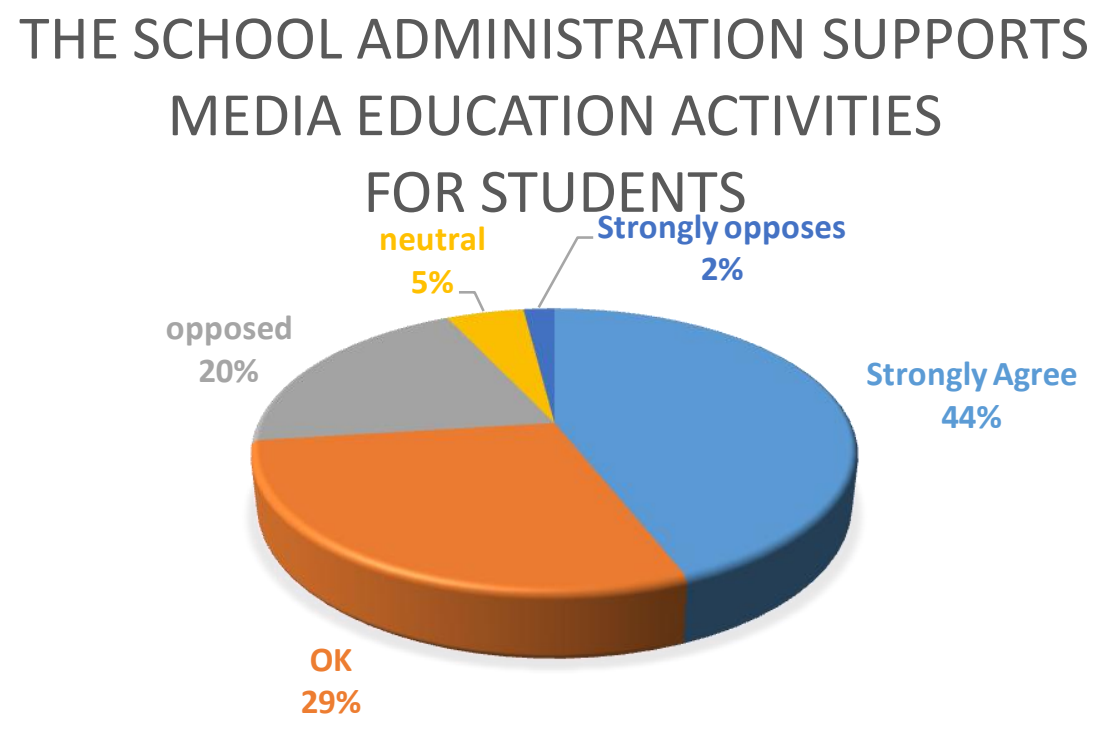

The questionnaire analysis on the research sample of secondary school teachers showed that the school supports media education activities for students by $44 \%$ agree, $29 \%$ strongly agree, $20 \%$ are neutral, $5 \%$ oppose, and $2 \%$ strongly oppose.

\section{THERE IS AN ACTIVATION OF THE MEANS OF TECHNOLOGY IN EDUCATION INFORMATIONAL SCHOOL} Strongly opposes

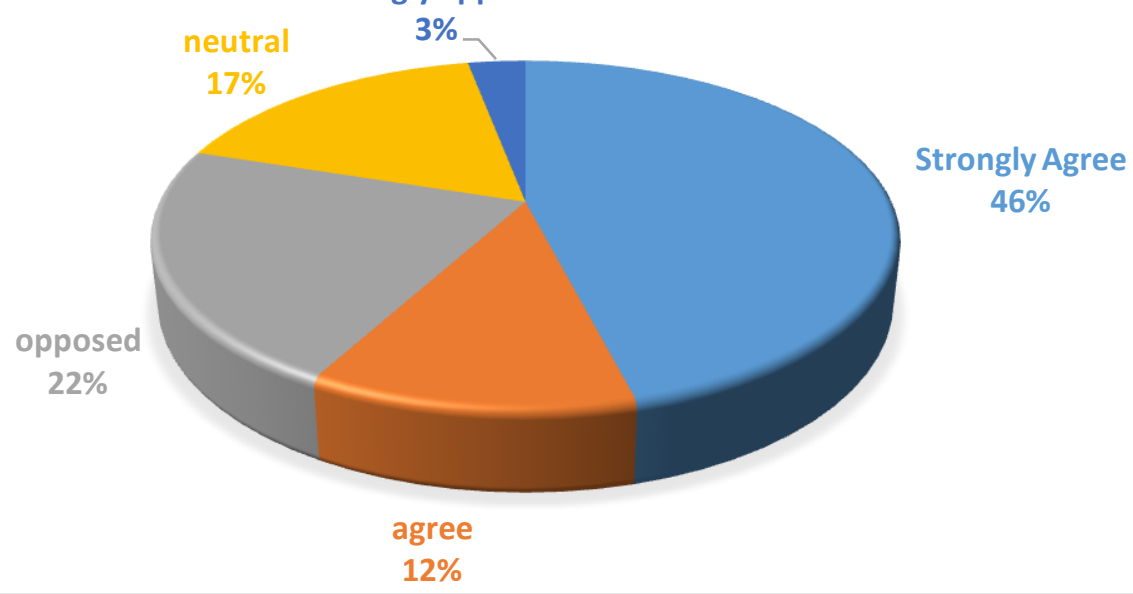


The analysis of the questionnaire on the research sample of secondary school teachers showed that there is an activation of technology in media education in the school, with a percentage of $46 \%$ who strongly agree, $12 \%$ agree, $22 \%$ oppose, $17 \%$ are neutral, and $3 \%$ strongly oppose.

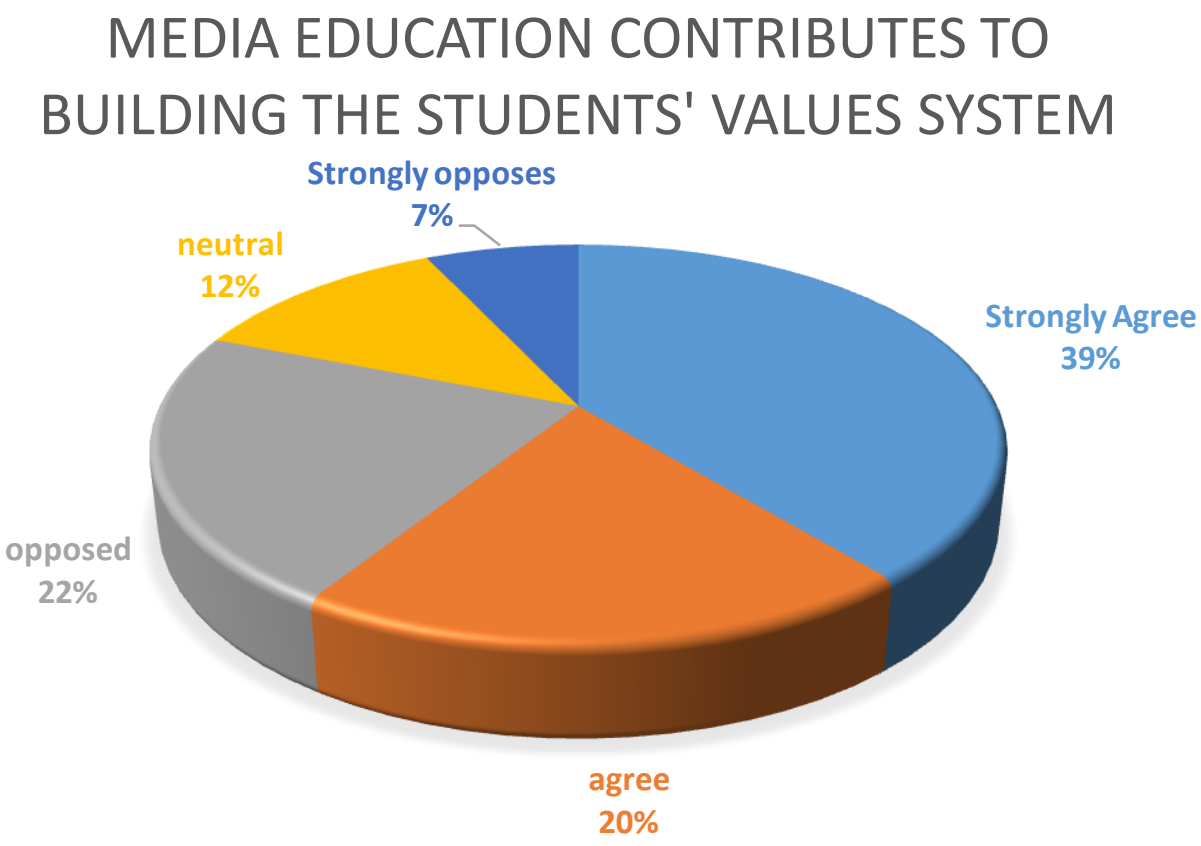

The questionnaire analysis on the research sample of secondary school teachers showed that media education contributes to building the students' values system, with $39 \%$ strongly agree, $20 \%$ strongly agree, $22 \%$ are neutral, $12 \%$ oppose, and $7 \%$ strongly oppose. 


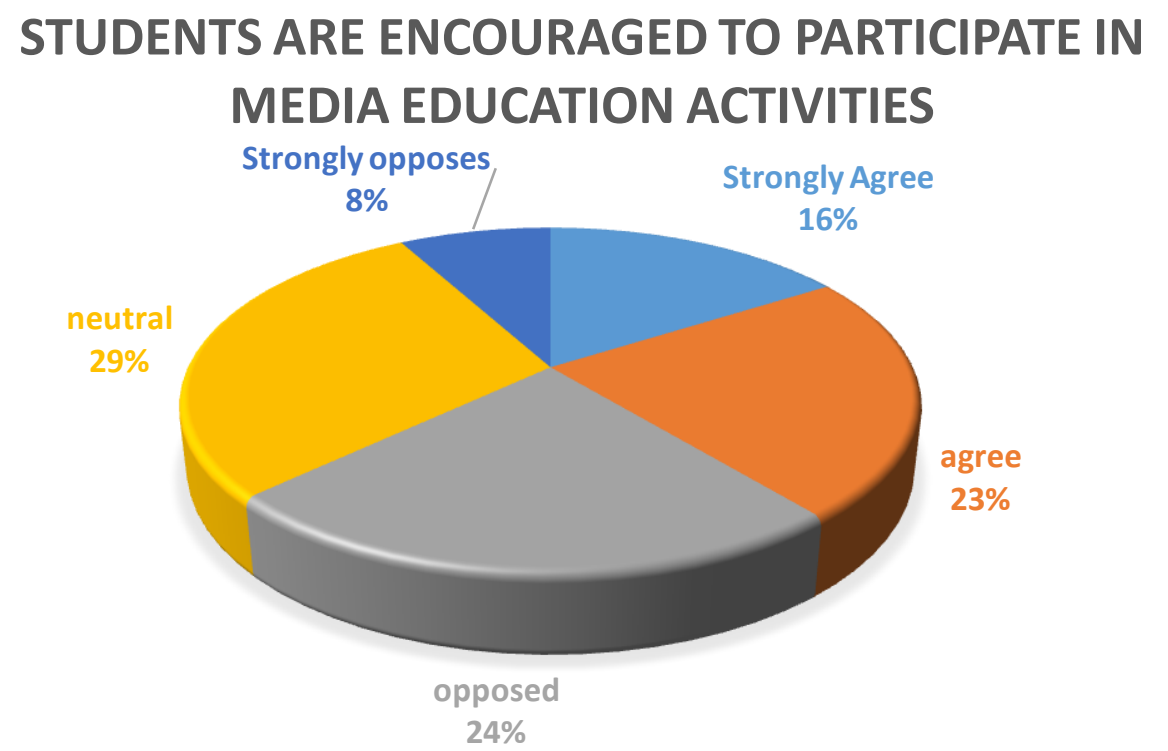

The questionnaire analysis on the research sample of secondary school teachers showed that students are encouraged to participate in media education activities, with a rate of $16 \%$ who strongly agree, $23 \%$ agree, $24 \%$ are neutral, $29 \%$ oppose, and $8 \%$ strongly oppose.

\section{MEDIA EDUCATION ACTIVITIES CONTRIBUTE TO SPREADING THE SPIRIT OF PATRIOTISM AND BELONGING AMONG STUDENTS}

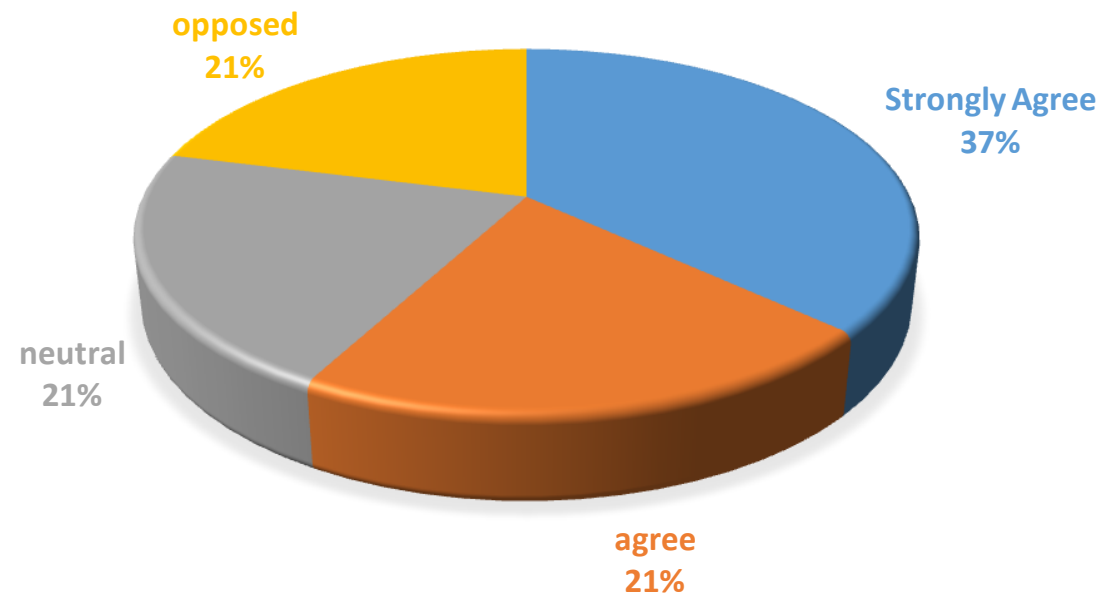


The questionnaire analysis on the research sample of secondary school teachers showed that media education activities contribute to spreading the spirit of patriotism and belonging among students, with $35 \%$ strongly agree, $20 \%$ agree, $20 \%$ are neutral, and $25 \%$ oppose.

\section{Interpretation of the results:}

- $85 \%$ of the research sample agree that media education helps students form their personalities.

- 39\% of the research sample agree that media education is significant and has prominent secondary school activities.

- $58 \%$ of the research sample agree that there is an activation of technology in media education in secondary schools.

- $32 \%$ of the research sample believes that there are many media education activities in secondary schools.

- 39\% of the research sample agree that students are encouraged to participate in media education activities.

- 59\% of the research sample agree that media education contributes to building high school students' value system. - 55\% of the research sample agrees that media education contributes to spreading the spirit of loyalty and belonging to the homeland among high school students.

\section{Conclusion:}

The current research confirms that information and education are the two wings of society that fly them in the space of science and knowledge and the open skies. To bring us to the so-called "media education", where the matter is limited to an awareness of the contents of the various types of media and enhance the capabilities of school students to understand and analyze what modern technological communications and multimedia offer in the information society. 


\section{Recommendations:}

To improve school educational media, the participant suggests some recommendations that achieve increasing the activation of the school's role in educational media, including:

1. Inviting educational institutions to optimal employment of media institutions' capabilities and mass communication means in the educational process's service.

2. Inviting media professionals and educators to coordinate between the education sector and the media sector in planning the educational content that can be presented to students.

3. Inviting media institutions to periodically evaluate media materials targeting students in light of media, educational, and psychological standards.

4. Inviting teachers to provide students with behavioral patterns that focus on developing critical thinking and social values that enable them to adapt to changing life patterns and equip them with the skills that enable them to gain an objective, scrutinizing view of things and situations. 


\section{References}

- Ahmad, Ahmad Jawhar (2004). Electronic Media: Reality and Prospects,

Egypt, Mansoura: Dar Al Kalima for Publishing and Distribution.

- Charles, Salmon, and John Balser (1417 A.H.). Public Opinion and Media:The Industry of Public Satisfaction, translated by Othman Al-Arabi, Riyadh: Dar The cub.

- Hareb, Saeed Abdullah (2003 AD) Challenges facing education In light of ontemporary global changes, a lecture given Commissioned by the Arab Bureau of Education for the Gulf States Riyadh: Arab Bureau of Education for the Gulf States.

- Habib, Majdi Abdel Karim (2003 AD) Teaching Thinking in an Era Information: Introduction, Concepts, Keys, Theories, Programs, Cairo: Arab Thought House.

- Hassan, Hassan Muhammad and others (1987 AD) An Introduction to Philosophies

Education, Cairo: Madbouly Library.

- Hamdan, Muhammad (2004 AD) the relationship between media and education in

The Arab World: What Problems? What Future? An introduction paper to Symposium of the Institute of Journalism and News Sciences in Tunis during the period 51-71 April 2004 AD.

- Khadour, Adeeb (2003) Security Media, Damascus: Eagle Press.

The role of media education and building the concept of sustainable development | Mervat Ibrahim 5352

- Al-Khatib, Muhammad Bin Shahat, and others (2004 AD) Fundamentals of Education Islamic, Riyadh: Al-Khuraiji House for Publishing and Distribution.

- Delor, Jack and others (1996). Learning that hidden treasure, Report of the International Commission on Education for the Twenty-first Century Twenty, Paris: UNESCO.

- Zaitoun, Hassan, and Hussein (2005) Teaching Thinking, Cairo: Scientist Books.

- Salem, Ahmad, and Adel Saraya (2003). Technology System Education, Riyadh: Al-Rashed Library.

- Suleiman, Ahmed (1991), the school radio for the two phases Middle and High School, Riyadh: Jeraisy Corporation for Distribution.

- Shehata, Hassan (2003 AD) Glossary of educational terms And Al-Nafsiah, Cairo: The Egyptian Lebanese House.

- Al-Sawy, Amina, and Abdulaziz Sharaf (1998 AD) The Media Theory in The Islamic Call, Cairo: Library of Egypt.

- Abdul Hafeez Moghadam (1991): The Role of Professional Guidance and Media in

Professional Choice and Compliance, El-Rawasi Magazine, Issue 04. Algeria, P .: 1

Abd Al-Raziq Muhammad Al-Dulaimi, the portal to the media and communication

House of Culture for Publishing Amman 2011 p. 17:18.

- Ajwa, Ali (2004) Media and Development Issues, Cairo: Scientist

Books, p.12.

- Omar, and others (2011) Educational Media, Taiba Publishing Corporation

Cairo p. 73

- Al-Ali, Ahmad Abdullah (2002 AD) Child and Cultural Education: A vision for the future of the twenty-first century, Cairo: Dar Al-Kitab the talk.

- Al-Owaini, Muhammad Ali (1983) International Islamic Media: Between Theory and Practice, Al-Ain: Dar Kazem.

- Metwally, Mustafa Muhammad (2004 AD) Introduction to the history of education

Islamic, Riyadh: Al-Khuraiji House for Publishing and Distribution.

- Metwally, Nabil Abd al-Khaleq Muhammad and his side Ibrahim al-Hilweh (1423 AH).

Strengthening the Islamic religious identity as a goal of the school of the future: Analytical study, seminar organized by the School of the Future 
- Makkawi, Hassan Emad (2005), Media and Crisis Management, Cairo: The Egyptian Lebanese House.

- Baranov, O. (2012). Media Education in School and University. (In Russian). Tier: State University, P. 87. 